\title{
Violence in Public Transport: An Analysis of Resilience and Vulnerability in the City of Rio de Janeiro
}

\author{
Violência no Transporte Público: Uma Análise da Resiliência \\ e Vulnerabilidade na Cidade do Rio de Janeiro
}

Marcus Hugo Sant'Anna Cardoso [a] [D], Tálita Floriano Santos [a.b] (iD),

Marcelino Aurélio Vieira da Silva [a] [i]

[a] Federal University of Rio de Janeiro, Transportation Engineering Program, Rio de Janeiro, RJ, Brazil

[b] Federal University of Piauí, Department of Production Engineering, Teresina, PI, Brazil

How to cite: Cardoso, M. H. S., Santos, T. F., \& Silva, M. A. V. (2021). Public safety and urban mobility: evaluation of vulnerability and resilience in the city of Rio de Janeiro. urbe. Revista Brasileira de Gestão Urbana, v. 13, e20200231. https://doi.org/10.1590/2175-3369.013.e20200231

\begin{abstract}
Indicators of violence involving public transportation have reached alarming levels in most Brazilian states, hampering mobility. This article aims to identify the level of vulnerability and resilience of public transportation in 21 administrative regions of the city of Rio de Janeiro, in light of criminal occurrences. Variables related to population, employment, intervening opportunities, travel time, criminal occurrences associated with public transportation and police coverage of each evaluated region were used. The results indicated that the five most vulnerable regions are Campo Grande, Méier, Barra da Tijuca, Rio Comprido and Irajá, and the most resilient are Lagoa, Copacabana, Botafogo, Vila Isabel and Tijuca. The contribution of this work is the proposal to analyze the level of vulnerability and resilience based on public security data, with emphasis on the spatial dependence relation among the regions.
\end{abstract}

Keywords: Public Transportation. Vulnerability. Resilience. Criminal Occurrences.

\section{Resumo}

Os indicadores de violência no entorno dos transportes públicos têm alcançado níveis alarmantes na maioria dos estados brasileiros, afetando inclusive sua mobilidade. Este artigo objetiva, utilizando a lógica nebulosa, identificar o nível de vulnerabilidade e de resiliência do transporte público em 21 regiões administrativas da cidade do Rio de Janeiro, em face das ocorrências criminais. Foram utilizadas variáveis relacionadas a população, emprego, oportunidades intervenientes, tempo, ocorrências criminais no entorno dos transportes públicos e cobertura policial de cada região avaliada. Os resultados permitem concluir que as cinco áreas mais vulneráveis são: Campo Grande, Méier, Barra da Tijuca, Rio Comprido e Irajá e as áreas mais resilientes são: Lagoa, Copacabana, Botafogo, Vila Isabel e Tijuca. A contribuição deste trabalho pode ser verificada pela proposta de analisar o nível de vulnerabilidade e de resiliência a partir de dados de segurança pública, com destaque para uma relação de dependência espacial das regiões.

Palavras-chave: Transporte Público. Vulnerabilidade. Resiliência. Ocorrências Criminais.

MHSC is civil engineer, MSc in Transport Engineering, e-mail: cardoso@pet.coppe.ufrj.br

TFS is industrial engineer, professor, PhD in Transport Engineering, e-mail: talitafloriano@pet.coppe.ufrj.br

MAVS is civil engineer, professor, PhD in Transport Engineering, e-mail: marcelino@pet.copp.ufrj.br 


\section{Introduction}

Epidemiological and criminal statistics show that social violence in Brazil has reached unprecedented magnitude and intensity, even higher than observed in some war zones (de Souza \& de Lima, 2006). The country has suffered in recent decades from expansion of organized crime and the consequent damages to society. Security is a subject that has long been a concern of Brazilian citizens (Carvalho \& Risso, 2018). According to Rolim (2007), the seriousness of the phenomena of violence and criminality in Brazil, with the emergence of unexpected situations capable of putting entire cities at risk, such as the terrorist practices constructed by the PCC in São Paulo, or by groups organized in Rio de Janeiro, it has not, however, allowed the offer of new and more effective responses in terms of public security policies.

On the contrary, exceptions aside, it is noteworthy that the policies implemented by different governments are almost always attempts to minister again, models that have already been tested and are known to be incapable of producing different results from the remarkable failure already accumulated (Rolim, 2007).

According to Moreira \& Fochezatto (2017), the growth of crime has intensely preoccupied public security policy makers, as the advance of different forms of violence has caused profound changes in society's lifestyle, especially in the way cities are organized.

According to Fajnzylber \& Araújo Jr (2001), surveys conducted with the population not only Latin American, but also North American and European, point out that, from the 1990s onwards, violence became the main concern of opinion overlapping themes such as unemployment, inflation, interest and taxes, themes that have long been of concern to the whole of society.

The growth of modern cities, following the period of industrialization, brought with it a new form of spatial organization of existing cities. In addition, the disorganized growth of urban space, resulting from this enormous pressure of population convergence, significantly changed the appearance of cities, as well as the type of life of their inhabitants, giving rise to the emergence of a specific criminality (Rolim, 2007).

The economic losses result from various criminal activities, such as cargo hijacking, extortion, drug gang violence, and cartel formation (FBSP, 2018), including crimes affecting public transport.

Users of public transportation are vulnerable to crime during their trips, in commuter trains, buses, vans and taxis, among others, causing them to change from one mode to another, or just to go on foot to work and home (Kruger \& Landman, 2007).

Crime and personal safety are the main fears inhibiting the use of public transport, despite studies related to its good reliability and accessibility (Newton, 2004). The use of public transport would increase by $11.5 \%$ if public worries about safety could be addressed adequately (Moore, 2011).

Daily in large Brazilian cities, bus drivers, conductors and passengers are exposed to sound and air pollution, traffic congestion and accidents, as well as acts of violence (Castro et al., 2017). Therefore, it is relevant to investigate how resilient urban areas can be to those acts of violence that happen on public transport and how vulnerable riders are to those threats.

The concept of resilience permits identifying a city's ability to respond to such threats and can be defined as the capability of a system to persist, adapt, transform, recover and absorb impacts (Gaitanidou et al., 2017; Marchese et al., 2018) due to internal or external threats. One the other hand, the concept of vulnerability involves the magnitude the community is able to absorb and also the pace of recovery when the community is faced with a threat. Besides this, the degree of vulnerability is related both to the nature of threats and resilience of the system (Langridge et al., 2006).

This article analyzes the resilience and vulnerability of public transport against crimes reported to the police in 21 administrative regions of the city of Rio de Janeiro, based on fuzzy logic. The article is organized in five more sections: urban violence; resilience and vulnerability; methodological procedures; results; and final considerations. 


\section{Urban Violence and Public Transport}

A survey conducted by the National Confederation of Industries (CNI, 2018) indicated that public safety was among the four greatest concerns of Brazilians, mentioned by $38 \%$ of the respondents. Crime affects not only users of public transport but also potential users (Kruger \& Landman, 2007).

Crime associated with public transport encompasses a wide range of violations, which can be classified into at least three types of situations: (i) while commuting to, from or between stations/terminals; (ii) while waiting at boarding points or deboarding; and (iii) on board the vehicle, e.g., a bus or train (Newton, 2004).

The level of violence also causes psychological damages, associated with the feeling of fear and intimidation by criminals. This subservience prompts a feeling of impotence and doubt about the ability of the public authorities to assure security (FBSP, 2018).

The fears related to violence and personal safety are important inhibiting factors that should be considered to understand the efficacy of public transportation, because they diminish the trust of many people and consequently their accessibility. Negative experiences during any part of the trip can influence demand due to fear, and with this change the travel patterns of passengers and even cause them to cease using public transportation.

Little information is available about the extent of crime and disorder while using public transport. Besides this, there are discrepancies regarding the real levels observed (Newton, 2014). The most likely reasons include the multiple agencies responsible for maintaining and operating the various public security systems, the lack of standardized records and reports of crimes and disorder, the difficulties of analyzing the available data, different policing and security strategies, and underreporting of crimes.

Violence associated with public transport undermines one of the basic rights of citizens - mobility besides having a deleterious effect on public health. Insecurity within vehicles impairs the quality of the service. Public transport plays an important role in reducing social exclusion, by providing access to activities such as pursuing health care, employment and leisure (Newton, 2014). In this respect, it is important to consider that since mobility is related to access to other places and opportunities, it has a direct impact on people's quality of life (Hernández, 2012). This poses an even greater challenge than reducing the risk of disasters and the related hazards (Spaans \& Waterhout, 2017), and affects people's daily routines and the functioning of the city.

The role of public transport is to stimulate sustainable urban social and economic development by meeting the needs of passengers (Proper \& Pienaar, 2011). The ongoing improvement of public transport is necessary, but often this occurs without adequate concern for the security against violence of users (Kooi, 2015). The effort to supply public transport more focused on the needs of users requires development of resilience in the sector. Better resilience can contribute to the process of adaptation, which includes a defensive and reactive strategy (Proper \& Pienaar, 2011).

Studies in cities around the world have shown that the problems of violence cannot be totally eliminated, but they can be controlled. However, projects over the medium to long range need to be established, and participation of the community is fundamental to tackle this problem more effectively (Carr \& Spring, 1993). Studies of the spatial trends of crime reveal that regional differences regarding the effects of contextual variables, such as anomie, deprivation, unemployment and poverty in cities, are critical determinants of the local level of criminality (Ajayi \& Ajayi, 2013).

\section{Resilience and Vulnerability}

Transportation networks are fundamental for the circulation of goods and people in the globalized market. Transportation systems are complex networks where the characteristics of resilience and vulnerability can be analyzed and examined from different standpoints (Reggiani et al., 2015).

The definition of resilience is the ability of systems to resist various disasters or problems and recover their normal operating situation (Xu \& Xue, 2017). It reflects the level of adaptability to risks, externalities 
and shocks of a system, to maintain or stabilize its functions (Gaitanidou et al., 2017). In other words, it denotes the ability of a network to maintain its connectivity even in the occurrence of an event that is unfavorable to its functionality (Kim \& Song, 2018).

Unlike the concept of resilience, vulnerability does not have a convergent definition. It can be associated with interruptions or susceptibility to certain damages. Vulnerability is the exposure of a city to shocks in terms of magnitude and frequency (Boschetti et al., 2017) or also the susceptibility to incidents that can in some way affect the system (Berdica, 2002). Here we define vulnerability as the susceptibility of a system to a determined threat. It is important to note that vulnerability is not necessarily the inverse of resilience. In some situations, the system can be resilient to a threat while at the same time being vulnerable.

The importance of recognizing areas of high vulnerability and improving their resilience by mitigating risks has attracted the interest regarding local and community development in academic and political circles (Wang et al., 2017). The reason is that resilience not only involves persistence, but also the opportunities that threats bring in terms of recombination of structures and processes, renovation of systems and emerging trajectories (Folke, 2006).

Therefore, it can be said that resilience of urban mobility is the ability of the system to prepare for, respond to and recover after an extreme event (Gaitanidou et al., 2017). A city can be more or less vulnerable to threats, hence the importance of identifying the threats that can affect mobility, such as urban violence.

\section{Methodological Procedures}

Fuzzy logic is a useful tool to resolve complex problems, given its ability to infer conclusions and produce responses based on ambiguity and/or qualitative, incomplete or imprecise information (Cosenza et al., 2016).

A typical model uses rules based on "If-Then" logic (e.g., "If ' $U$ ' is near 50, Then ' $V$ ' is large"). More formally, the process used to determine the output from an input is called inference. Each link corresponds to a set of fuzzy rules, called an inference block (IB), in which the linguistic variables are computed by aggregation and composition, so as to produce an inferred result, also in the form of a linguistic variable (Cury, 2007). Each inference block has a set of rules considering linguistic values.

In this section we describe the application of fuzzy logic to measure the levels of resilience and vulnerability of the administrative regions of the city of Rio de Janeiro. Of the 33 such regions, we chose 21, based on available data on the occurrence of crimes and consistent police crime fighting efforts during the 12-month period analyzed. The methodological steps used were based on the procedure developed by Santos et al. (2020).

\section{Fuzzy System Modelling}

Using fuzzy concepts, evaluators can use linguistic terms to assess indicators in a natural language expression, where each linguistic term is associated with a membership function. Then, the necessary concepts of fuzzy system modelling is described as follows (Vinodh \& Devasan, 2011; Sałabun et al., 2019; Yager, 2000; Sałabun, 2014; Faizi et al., 2018), based on the work Santos et al. (2020).

Definition 1. Fuzzy set and membership function. The characteristic function $\mu_{\mathrm{A}}$ of a crisp set $A \subseteq \mathrm{X}$ assigns a value of either 0 or 1 to each member in $\mathrm{X}$, since crisp sets only allow full membership $\left(\mu_{A}(x)=\right.$ 1 ) or non-membership $\left(\mu_{A}(x)=0\right)$. This function can be generalized to a function $\mu_{A}$ such that the value assigned to the element of the universal set $X$ falls within a specified range, i.e., $\mu_{\tilde{A}}: X \rightarrow[0,1]$. The assigned value indicates the membership grade of the element in set $A$. The function $\mu_{\tilde{A}}$ is called the membership function and the set $\tilde{\mathrm{A}}=\left(\mathrm{x}, \mu_{\tilde{\mathrm{A}}}(x)\right)$, where $x \in \mathrm{X}$, defined by $\mu_{\tilde{\mathrm{A}}}(x)$ for each $x \in \mathrm{X}$, is called a fuzzy set.

Definition 2. Triangular fuzzy number. A fuzzy set $\tilde{A}$, defined on the universal set of real numbers $\Re$, is said to be a triangular fuzzy number $\tilde{A}(a, m, b)$ if its membership function has the following form according to equation 1: 


$$
\mu_{\tilde{\mathrm{A}}}(x, a, m, b)=\left\{\begin{aligned}
0, & x \leq a \\
\frac{\mathrm{x}-\mathrm{a}}{\mathrm{m}-\mathrm{a},} & a \leq x \leq m \\
1, & x=m \\
\frac{\mathrm{b}-\mathrm{x}}{\mathrm{b}-\mathrm{m},} & m \leq x \leq b \\
0, & x \geq a
\end{aligned}\right.
$$

And the following characteristics (equations 2, 3):

$$
\begin{aligned}
& x_{1}, x_{2} \in[a, b] \wedge x_{2}>x_{1} \Rightarrow \mu_{\tilde{\AA}}\left(x_{2}\right)>\mu_{\tilde{\AA}}\left(x_{1}\right) \\
& x_{1}, x_{2} \in[b, c] \wedge x_{2}>x_{1} \Rightarrow \mu_{\tilde{\AA}}\left(x_{2}\right)>\mu_{\tilde{\AA}}\left(x_{1}\right)
\end{aligned}
$$

Definition 3. Trapezoidal fuzzy number. A fuzzy set $\tilde{A}$, defined on the universal set of real numbers $\Re$, is said to be a trapezoidal fuzzy number, such as $\tilde{\mathrm{A}}(x, a, b, c, d)$, if its membership function has the following form (equation 4):

$$
\mu_{\tilde{\mathrm{A}}}(x, a, b, c, d)=\left\{\begin{array}{rc}
0, & x \leq a \\
\frac{\mathrm{x}-\mathrm{a}}{\mathrm{b}-\mathrm{a}}, & a \leq x \leq b \\
1, & b \leq x \leq c \\
\frac{\mathrm{d}-\mathrm{x}}{\mathrm{d}-\mathrm{c}}, & c \leq x \leq d \\
0, & d \leq x
\end{array}\right.
$$

Definition 4. Symbolically, $\tilde{\mathrm{A}}$ is denoted by $\mu_{\tilde{\mathrm{A}}}(x, a, b, c, d)$. The generalized trapezoidal fuzzy number $\tilde{\mathrm{A}}=(x, a, b, c, d)$ divides into three parts: the left part, middle part, and right part.

Definition 5. Gaussian fuzzy number. A fuzzy set $\tilde{A}$, defined on the universal set of real numbers $\Re$, is said to be a Gaussian fuzzy number, such as $\tilde{A}(x, c, s, m)$, if its membership function has the following form as given by equation 5 :

$$
\mu_{\tilde{\mathrm{A}}}(x, c, s, m)=\exp \left[-\frac{1}{2}\left|\frac{x-c}{s}\right|^{m}\right]
$$

Where $\mathrm{c}$ is the centre, $\mathrm{s}$ is width, and $\mathrm{m}$ is the fuzzification factor.

Definition 6. The rule base. The rule base consists of logical rules determining causal relationships that exist in the system between fuzzy sets of its inputs and its output.

Definition 7. The fuzzy rule. The single fuzzy rule can be based on a modus ponens. The reasoning process uses logical connectives IF-THEN, OR, and AND.

Definition 8. A typical fuzzy model employs rules based on "IF-THEN". More formally, the process used to determine the output for a given input is called fuzzy inference. Based on this inference, the output is called the pertinence degree, with values ranging from 0 to 1 , and is determined by equation 6 :

$$
\mathrm{E}_{\mathrm{i}}(\mathrm{y})=\mathrm{T}\left(\tau_{\mathrm{i}} \mathrm{B}_{\mathrm{i}}(\mathrm{y})\right)
$$

where $E_{\mathrm{i}}$ is a fuzzy subset., $\tau_{\mathrm{i}}$ is the degree of the function, and $B_{\mathrm{i}}$ is the fuzzy subset of linguistic concepts defined in space $y$.

Definition 9. For the method considering the "AND" rules of a set of variables (for example, IF employment in the destination is high AND the population of the origin is high, THEN the potential use of transportation is high), then (equation 7 and 8):

$$
\begin{array}{ll}
\mathrm{T}\left(\tau_{\mathrm{i}} \mathrm{B}_{\mathrm{i}}(\mathrm{y})\right)=\tau_{\mathrm{i}}^{\wedge} \mathrm{B}_{\mathrm{i}}(\mathrm{y}) \quad(\wedge=\min ) \\
\mathrm{T}\left(\tau_{\mathrm{i}} \mathrm{B}_{\mathrm{i}}(\mathrm{y})\right)=\tau_{\mathrm{i}} \mathrm{B}_{\mathrm{i}}(\mathrm{y}) \quad \text { (output) }
\end{array}
$$

Besides this, the operator $S\left(E_{1}(y), E_{2}(y), \ldots E_{n}(y)\right)$, for the method that considers the union of rules with "OR", involves equations 9 and 10 . 


$$
\begin{gathered}
S\left(E_{1}(y), E_{2}(y), \ldots, E_{n}(y)\right)=\operatorname{Max}_{\mathrm{i}}\left(E_{\mathrm{i}}(y)\right) \\
S\left(E_{1}(y), E_{2}(y), \ldots, E_{n}(y)\right)=1-\Pi\left(1-E_{i}(y)\right)
\end{gathered}
$$

Definition 10. To obtain a crisp output, it is necessary to defuzzify the result denoted by $y^{*}$, according to the centroid method, as given by equation 11 .

$$
\mathrm{y}^{*}=\frac{\sum_{\mathrm{y}} \mathrm{E}(\mathrm{y}) \mathrm{y}}{\sum_{\mathrm{y}} \mathrm{E}(\mathrm{y})}
$$

\section{Input variables}

The proposed procedure presents a hierarchical architecture of the problem (measuring the level of resilience and vulnerability), in a combination of blocks of inference that uses fuzzy rule based on linguistic expressions, for each variable to be expressed by means of a value. The structure of the procedure is fundamentally based on the input variables of a quantitative nature based on these data: population, employment, income, police station, number of crimes in public transport, and trip time using public transport. The procedure uses 9 input variables and transforms these into linguistic variables (very low, low, medium, high and very high), with the respective degrees of certainty for each block of inference. Table

\begin{tabular}{|c|c|c|}
\hline Input Variables & Description & Source \\
\hline Population (origin) & Referring to population in administrative region of origin & Census Data (2010) \\
\hline $\begin{array}{l}\text { Employment } \\
\text { (destination) }\end{array}$ & Referring to jobs in administrative region of destination & $\begin{array}{l}\text { Annual Report of Social } \\
\text { Information }\end{array}$ \\
\hline $\begin{array}{l}\text { Intervening } \\
\text { opportunities }\end{array}$ & Number of jobs that can be reached until destination & $\begin{array}{l}\text { Annual Report of Social } \\
\text { Information and Google API } \\
\text { (time) }\end{array}$ \\
\hline Trip time & Time required to reach destination & Google API \\
\hline Occurrence index & $\begin{array}{l}\text { Measures the ratio between the number of crimes } \\
\text { associated with public transport and the population of } \\
\text { each region }\end{array}$ & $\begin{array}{l}\text { Institute of Public Security of } \\
\text { Rio de Janeiro }\end{array}$ \\
\hline Index Police Base & $\begin{array}{l}\text { Measures the ratio between the number of police based } \\
\text { and the population of each region }\end{array}$ & $\begin{array}{l}\text { Institute of Public Security of } \\
\text { Rio de Janeiro }\end{array}$ \\
\hline Average time & $\begin{array}{l}\text { The average time taken to travel from each } \\
\text { administrative region to the other regions by public } \\
\text { transportation }\end{array}$ & Google API \\
\hline Jobs (60 minutes) & $\begin{array}{l}\text { Number of jobs that can achieve } 60 \text { minutes using public } \\
\text { transport }\end{array}$ & $\begin{array}{l}\text { Annual Report of Social } \\
\text { Information and Google API } \\
\text { (time) }\end{array}$ \\
\hline Income (origin) & Average nominal income & Census Data (2010) \\
\hline
\end{tabular}
1 shows the description of input variables.

Table 1 - Description of input variables

Source: Authors (2020).

We used the following input variables: population, employment, number of jobs within travel time of 60 minutes, trip time, income, police coverage (number of police stations), and number of crimes committed involving public transport. The demographic data (population and income) were obtained from the "Armazém dos Dados" ("Data Warehouse") for 2010, based on data collected in the census conducted that year by the Brazilian Institute of Geography and Statistics (IBGE), while the employment data were collected from the Annual Report of Social Information (RAIS), submitted by companies to the Labor Ministry, covering 2017. 
The "trip time" variable was obtained from Google (Maps and API), considering the average time taken to travel from each administrative region to the other regions by public transportation. The number of police stations and number of criminal occurrences were obtained from the Institute of Public Security of Rio de Janeiro. We used these data to calculate the occurrence index, which is the ratio between the number of crimes associated with public transport and the population of the region. The police coverage index was computed analogously.

After the input variables have been defined, we defined the sets generic fuzzy for all input variables, which present five levels of linguistic terms: very low, low, medium, high and very high. For the variable of employment, we added one more level of linguistic term: extremely high. This is because the input variable of employment presents the administrative region of the center with very different values from the other regions. Figure 1 shows a general membership function plots that were defined for all variables (inputs and outputs).

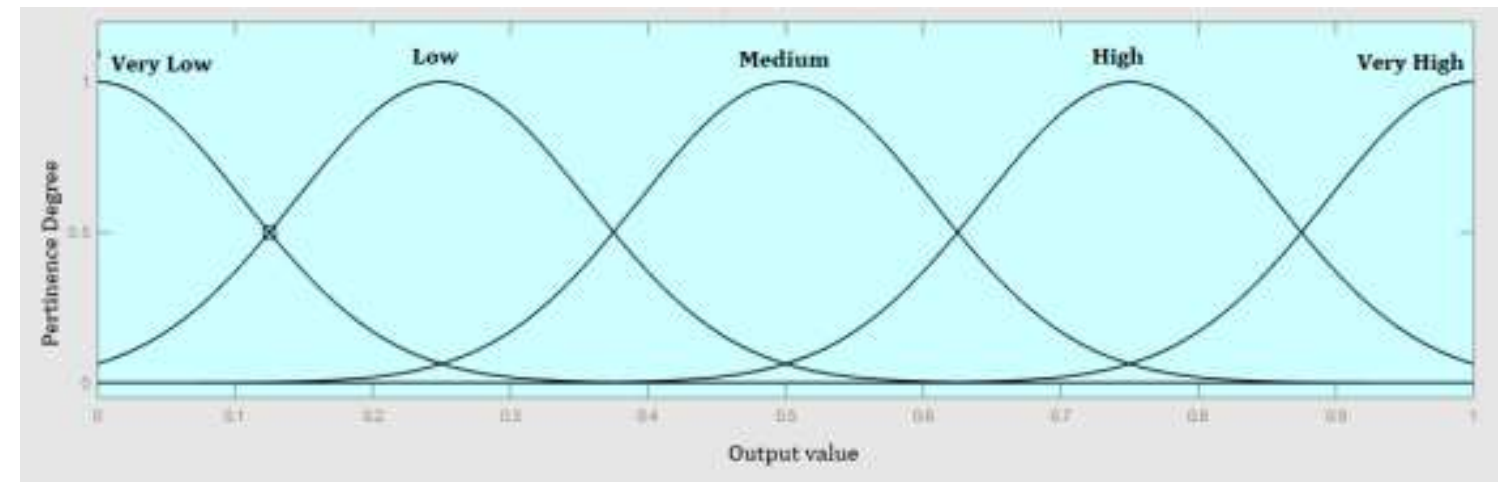

Figure 1 - Membership function. Source: Authors (2020).

\section{Fuzzy Logical Architecture}

For this study, we created seven inference blocks. In inference block 1, the potential for use considers the population of the origin region with employment in the destination region. For example, if the population of the origin is high and employment in the destination is also high, then the potential for use is high. Inference block 2, among other rules, considers that if the intervening opportunities are high until reaching the destination and the travel time is high, then the impedance is high. The flow level consists of the relation between the potential for use and the impedance: if the potential is high and the impedance is low, then the flow level will be high. In inference block 4, if the occurrence index is high and the police coverage index is low, then the violence factor will be high. Table 2 presents the rules created with the certainty factor when the destination employment is "very low".

Table 2 - Base of fuzzy rules for inference block 1 for "very low" employment

\begin{tabular}{llll}
\hline IF & & THEN & \\
\hline Destination & Origin Population & Potential for Use & Certainty Factor \\
Employment & & & \\
Very Low & Very Low & Very Low & 1 \\
Very Low & Low & Very Low & 0.95 \\
Very Low & Medium & Low & 0.85 \\
Very Low & High & Medium & 0.7 \\
Very Low & Very High & Medium & 0.8 \\
\hline
\end{tabular}

Source: Authors (2020)

The architecture of the problem has nine input variables and always two variables converging to their nodes, a total of seven nodes of logical architecture. In the seven nodes were defined a total of 180 rules. 
Figure 2 depicts the problem's logical architecture, with data from the 21 administrative regions of Rio de Janeiro.

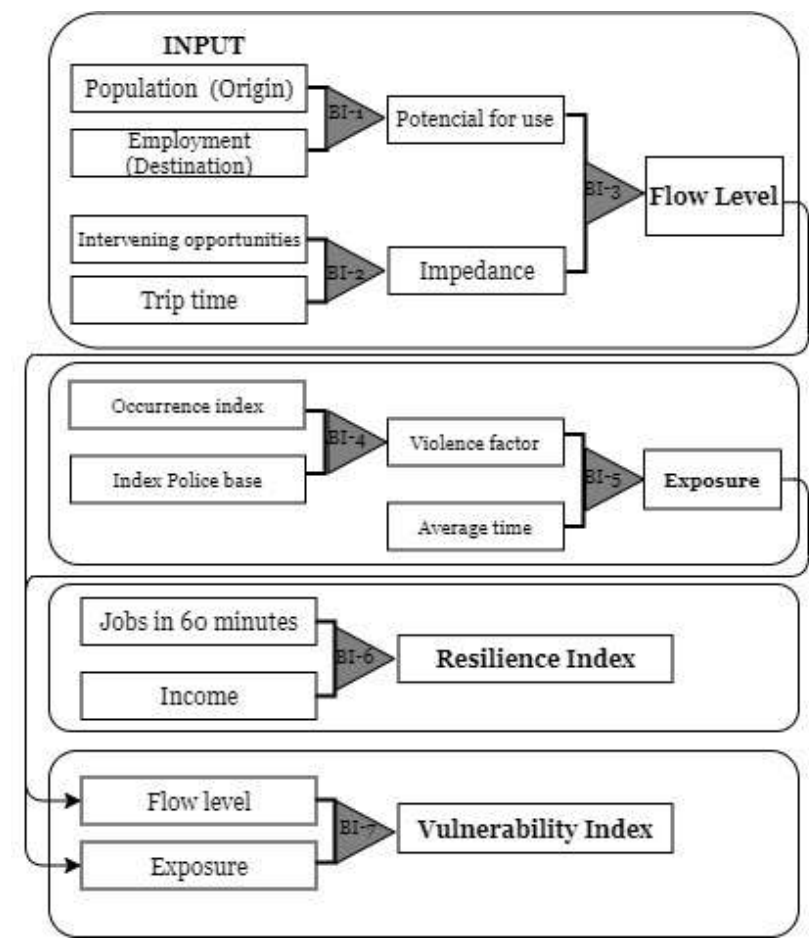

Figure 2 - Logical Architecture of the Problem. Source: Authors (2020).

As indicated in Figure 2, the resilience index was defined with the following inputs: number of jobs that the workers of a region can access in up to 60 minutes, and the region's average household income. The justification for choosing these variables to measure resilience is the fact that if a region manages to access a large number of jobs within 60 minutes, this implies, besides the existence of more than one transport modality available to the region, its proximity to regions like Centro, Botafogo and Barra da Tijuca (together responsible for approximately $40 \%$ of the formal jobs in the city). The choice of income converges with other factors in transport engineering, such as land use and availability of transport modes. For this reason, we defined that regions able to access a large number of jobs within 60 minutes, with very high income, have very high resilience index. The description of each inference block is described in Table 3.

Table 3 - Description of inference blocks

\begin{tabular}{|c|c|c|}
\hline $\begin{array}{l}\text { Output } \\
\text { Variables }\end{array}$ & Description & $\begin{array}{l}\text { Inference } \\
\text { block }\end{array}$ \\
\hline Potential use & $\begin{array}{l}\text { Measures O-D link that can be used based on population and employment } \\
\text { variables }\end{array}$ & $\begin{array}{l}\text { Inference } \\
\text { block } 1\end{array}$ \\
\hline Impedance & Measures the opposition to movement & $\begin{array}{l}\text { Inference } \\
\text { block } 2\end{array}$ \\
\hline Flow Level & Measures O-D link flow considering impedance and potential use & $\begin{array}{l}\text { Inference } \\
\text { block } 3\end{array}$ \\
\hline $\begin{array}{l}\text { Violence } \\
\text { factor }\end{array}$ & $\begin{array}{l}\text { Measures the violence factor based on the occurrence index and index } \\
\text { police base }\end{array}$ & $\begin{array}{l}\text { Inference } \\
\text { block } 4\end{array}$ \\
\hline Exposure & $\begin{array}{l}\text { Measures the exposure of each administrative region based on violence } \\
\text { factor and average time }\end{array}$ & $\begin{array}{l}\text { Inference } \\
\text { block } 5\end{array}$ \\
\hline $\begin{array}{l}\text { Resilience } \\
\text { Index }\end{array}$ & $\begin{array}{l}\text { Measures the resilience index based on number of jobs that can reach in } 60 \\
\text { minutes and the income of each administrative region }\end{array}$ & $\begin{array}{l}\text { Inference } \\
\text { block } 6\end{array}$ \\
\hline $\begin{array}{l}\text { Vulnerability } \\
\text { level }\end{array}$ & Measures the vulnerability level based on flow level and exposure & $\begin{array}{l}\text { Inference } \\
\text { block } 7\end{array}$ \\
\hline
\end{tabular}

Source: Authors (2020). 


\section{Results and Discussion}

The criminality data demonstrate that violence affects virtually all urban systems used by the people of Rio de Janeiro when carrying out their routine activities, including mobility. This means to say that public transport in the city is affected by insecurity and violence.

It should be noted that the crime maps prepared by the public security authorities contain inevitable gaps. The reason is that due to factors such as lack of trust in police, fear of possible reprisals by criminals, feeling of shame in reporting certain situations or even lack of first-hand knowledge, a significant problem of underreporting crimes exists.

Therefore, in the city of Rio de Janeiro we only considered the 21 administrative regions in which the Public Security Institute (ISP/RJ) was able to gather substantial information about criminality affecting public transport in 2017.

For these 21 administrative regions, we evaluated factors that, when combined, demonstrate the main characteristics of each one regarding the use of public transport. The administrative region with the greatest availability of public transport was Centro (downtown), since it is served by five modes: ferry boat (connecting to other cities across Guanabara Bay, and hence disregarded in this study), bus, commuter train, subway, and (most recently) a light rail vehicle (LRV) system. In relation to the number of police stations, Centro has the highest number with six, making this the region with the best geographic coverage.

We then grouped all the criminal occurrences involving public transport. Despite having the largest number of police stations, Centro presented the largest number of criminal occurrences associated with public transport, with 19,145 reported occurrences in 2017.

With respect to the level of vulnerability, the results demonstrated that the five regions most vulnerable to criminality affecting public transport were Campo Grande, Méier, Barra da Tijuca, Rio Comprido and Irajá. Campo Grande has the second highest population of the city's administrative regions. Although not having the largest number of reported crimes among the five most vulnerable regions, it has the lowest police coverage, given its high population density: 542,084 people with only two police stations. Another contributing factor is its average household income. Of the five most vulnerable regions Campo Grande had the lowest nominal income. The statistics are displayed in Table 4.

Table 4 - Regions with highest vulnerability indices

\begin{tabular}{|c|c|c|c|c|c|c|}
\hline $\begin{array}{l}\text { Administrative } \\
\text { Region }\end{array}$ & $\begin{array}{l}\text { Criminal } \\
\text { Occurrences }\end{array}$ & $\begin{array}{l}\text { Police } \\
\text { Coverage } \\
\text { (stations) }\end{array}$ & $\begin{array}{l}\text { Modes of Public } \\
\text { Transport } \\
\text { Available }\end{array}$ & Population & $\begin{array}{l}\text { Household } \\
\text { Income } \\
\text { (R\$/month) }\end{array}$ & $\begin{array}{l}\text { Vulnerability } \\
\text { Index }\end{array}$ \\
\hline Campo Grande & 14,155 & 2 & 2 & 542,084 & 737 & 0.74 \\
\hline Méier & 18,399 & 5 & 3 & 397,782 & 1,271 & 0.73 \\
\hline Barra da Tijuca & 17,716 & 3 & 3 & 300,823 & 3,244 & 0.72 \\
\hline Rio Comprido & 5,246 & 2 & 3 & 78,975 & 967 & 0.71 \\
\hline Irajá & 10,198 & 4 & 3 & 202,952 & 1,001 & 0.71 \\
\hline
\end{tabular}

Source: Authors (2020)

The vulnerability index map of the chosen regions is presented in Figure 3. 


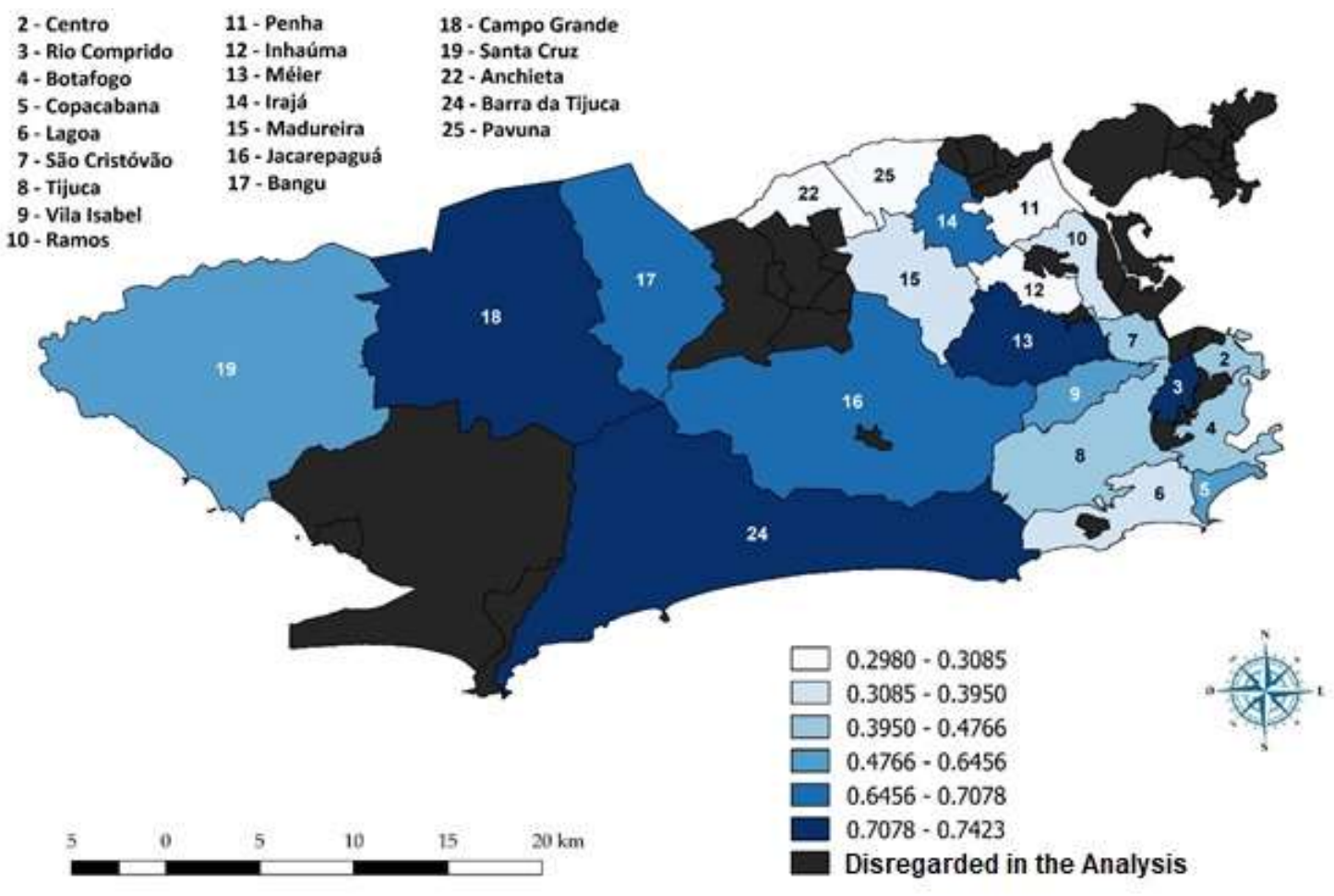

Figure 3 - Level of vulnerability of public transport regarding criminal occurrences. Source: Authors (2020)

Figure 3 and Table 4 together show that despite having the highest population among the five most vulnerable regions, Campo Grande has the fewest modes of public transport (only bus and commuter train). All these factors combined explain why Campo Grande was found to be the most vulnerable region in this analysis.

With respect to resilience, Lagoa had the highest capacity to react to crimes related to public transport. This administrative region is composed of seven districts and is served by the 23rd Military Police Battalion and the 14th and 15th Civil Police Stations ${ }^{1}$. Table 5 presents the administrative regions with the highest resilience indices and their respective criminal occurrences, police coverage, availability of public transport, income and population.

Table 5 - Regions with highest resilience indices

\begin{tabular}{lllllll}
\hline $\begin{array}{l}\text { Administrative } \\
\text { Region }\end{array}$ & $\begin{array}{l}\text { Criminal } \\
\text { Occurrences }\end{array}$ & $\begin{array}{l}\text { Police } \\
\text { Coverage } \\
\text { (stations) }\end{array}$ & $\begin{array}{l}\text { Modes of Public } \\
\text { Transport } \\
\text { Available }\end{array}$ & $\begin{array}{l}\text { Population } \\
\text { Household } \\
\text { Income } \\
\text { (RS/month) }\end{array}$ & $\begin{array}{l}\text { Resilience } \\
\text { index }\end{array}$ \\
\hline Lagoa & 9,288 & 3 & 2 & 167,774 & 4,643 & 0.918 \\
Copacabana & 10,817 & 3 & 2 & 161,191 & 3,229 & 0.917 \\
Botafogo & 5,742 & 3 & 2 & 239,729 & 3,306 & 0.917 \\
Vila Isabel & 3,221 & 3 & 3 & 189,310 & 2,009 & 0.748 \\
Tijuca & 8,169 & 3 & 3 & 181,810 & 2,424 & 0.748 \\
\hline
\end{tabular}

Source: Authors (2020)

Figure 4 present a map with the resilience level of the regions regarding criminal occurrences. Note that the three regions with the highest resilience levels are concentrated in the city's South Zone. 1 The Military Police is the uniformed police constabulary while the Civil Police is the investigative force. Both are
under state control. The city of Rio de Janeiro also has a Municipal Guard (unarmed), not considered here. 


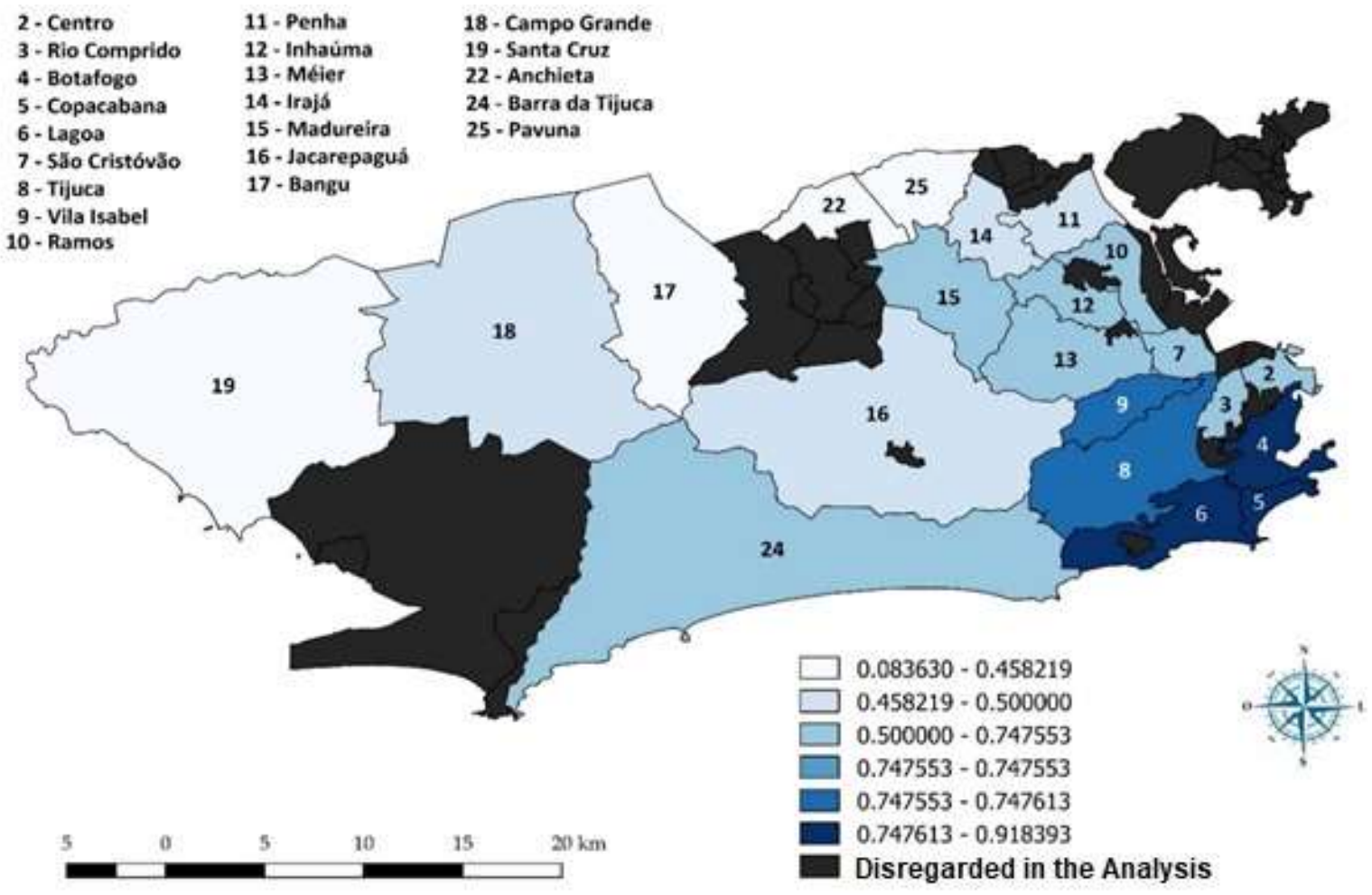

Figure 4 - Resilience level of public transport regarding criminal occurrences. Source: Authors (2020)

Figure 5 presents a graph with the vulnerability and resilience index of each of the administrative regions, divided into six sections. Section I contains the region of Santa Cruz, considered the worst in the analysis due to the high vulnerability index and low resilience index. Although not among the 10 regions highlighted for having high indices, the results point to Santa Cruz as the least resilient among the regions analyzed here. It is policed by one Military Police battalion and two Civil Police stations, serving a population of 368,534 , considered as providing insufficient coverage due to the existence more than 8,000 crimes related to public transportation in the year analyzed.

Section II contains the regions of Bangu, Campo Grande, Jacarepaguá and Irajá. The first three are located in the city's West Zone while Irajá is located in the North Zone. They have resilience index between 0.37 and 0.50 and vulnerability index from 0.67 to 0.74 . The regions in section III have vulnerability indices around 0.30 and a resilience index that varies between 0.55 and 0.68 . Its three regions are located in the city's North Zone.

Section IV contains the regions of Méier, Rio Comprido, Vila Isabel and Barra da Tijuca. The first three are in the North Zone while Barra da Tijuca is located in the West Zone. The vulnerability index varies between 0.63 and 0.73 and the resilience index between 0.51 and 0.61 . Section $V$ contains the regions of Inhaúma, Madureira, Ramos, Tijuca, São Cristóvão and Centro. The first five are situated in the North Zone. The vulnerability index ranges from 0.30 to 0.47 and the resilience index has values near 0.72 . Finally, section VI contains three regions, Copacabana, Botafogo and Lagoa, all located in the South Zone, near Centro. These regions have on average the highest income level in the city and are served by buses and the subway system. This combination allows accessing a large number of jobs with low commuting time. 


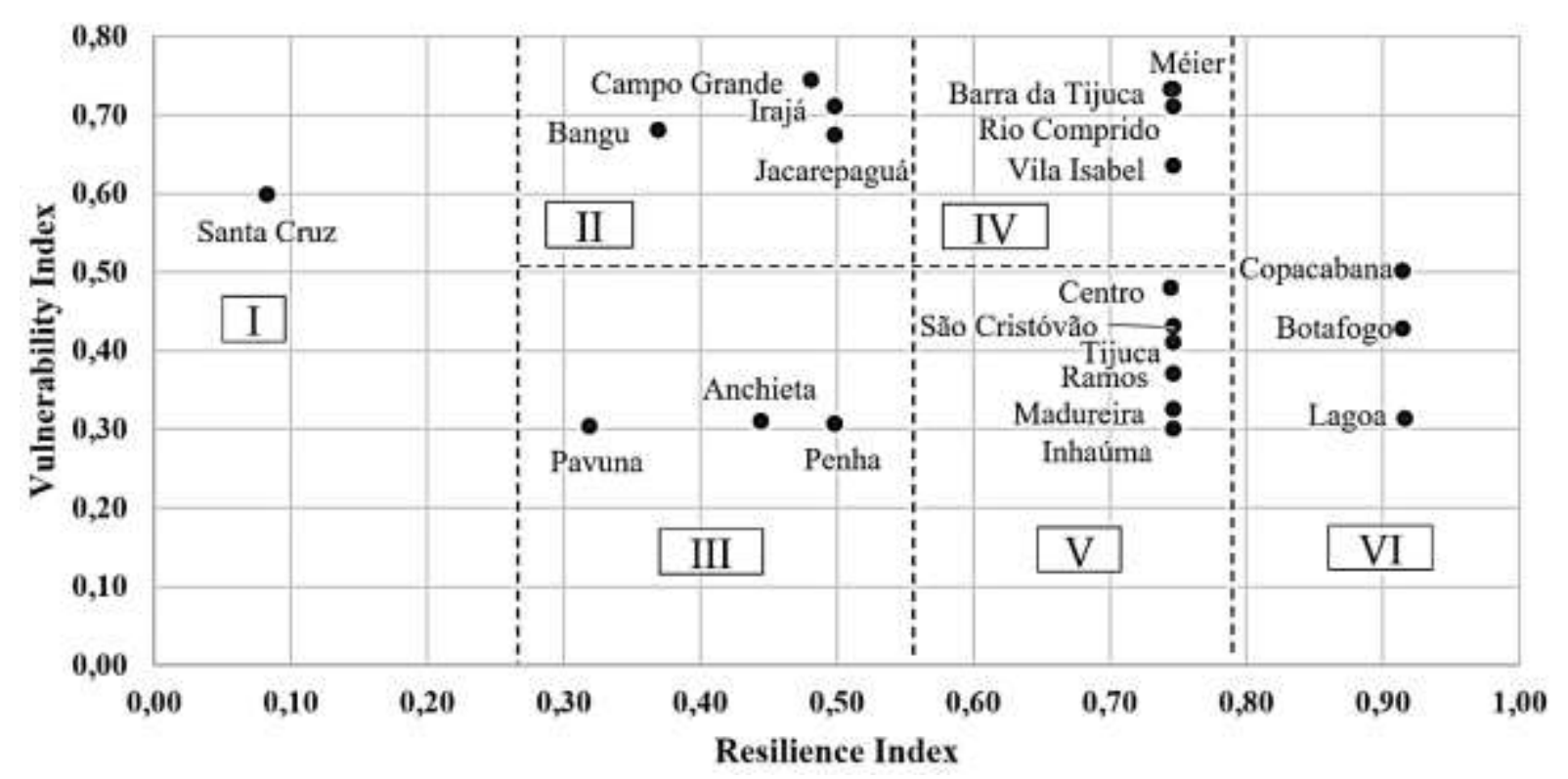

Figure 5 - Resilience and vulnerability indices of the chosen administrative regions. Source: Authors (2020)

This region does not have the lowest number of criminal occurrences related to public transport, does not have the greatest police coverage (despite a population of 167,774 people), but does have the highest nominal income. This shows once again that the economic factor has high capacity to enhance the resilience of a given region in response to urban violence.

The division observed in Figure 5 demonstrates that the most resilient regions are those in the South Zone of Rio de Janeiro, and the resilience and vulnerability indices in the six sections corroborate the spatial dependence among the regions.

\section{Final Considerations}

The state of Rio de Janeiro was a pioneer in creating its Public Safety Institute (ISP/RJ), through State Law 3,329 of December 28, 1999. It has the objective of gathering information, disseminating studies and analyses to support implementation of public safety policies, and assuring social participation in the formulation of these policies.

The ISP/RJ collects data on criminality throughout the state, to supply law enforcement authorities and public policymakers with useful information on fighting crime. This information enhances the potential effectiveness of security policies, involving tactical actions, strategic planning and definition and delegation of responsibilities.

The concept of resilience considered here consists of the ability of a system to continue functioning even after a shock or rupture. The threats most discussed in the literature regarding public transport involve the effects of natural disasters or technical flaws in the system. However, we noted a gap regarding public security. This study applied fuzzy logic with the aim of measuring the level of resilience and vulnerability of 21 administrative regions in the city of Rio de Janeiro from the standpoint of violence. For this purpose, we chose variables that can be related to the use of public transport and the number of criminal occurrences related to that transport (at stations/terminals, bus stops and aboard vehicles).

We analyzed data on public safety obtained from various sources, and by applying fuzzy logic measured the level of resilience and vulnerability of the 21 administrative regions regarding criminality associated with public transport. The results revealed that Campo Grande was the region most vulnerable to criminal occurrences associated with public transportation (with the second most inhabitants but police coverage disproportional to its population), while Lagoa was most resilient in this respect. In turn the region with the worst overall ranking was Santa Cruz. Despite the large transit system serving the region, the low nominal 
income of the population ( $\mathrm{R} \$ 527.00$ per month) increases its economic vulnerability, and thus the vulnerability to criminal actions.

The results of this study serve to promote reflection about public policies related to violence, vulnerability and resilience. In particular, the income level of the regions has a strong relationship with their resilience and vulnerability, as well as spatial dependence.

A final point worth mentioning is the division in Brazil between the Military Police and Civil Police. As mentioned in the footnote, the former force has responsibility for ostensive policing, mainly through patrolling by car and presence at neighborhood booths/posts, while the latter has responsibility for investigating crimes. These two forces need to work more effectively together (if not being merged), to enable reducing criminality in Rio de Janeiro, with the support of better informed public policies.

\section{References}

Ajayi, A. P., \& Ajayi, D. D. (2013). Areal differentiation in crime in public transit terminals in Ibadan metropolis. Journal of Transporation Security, 6(1), 1-12. doi: 10.1007/s12198-012-0099-2.

Berdica, K. (2002). An introduction to road vulnerability: What has been done, is done and should be done. Transport Policy, 9(2), 117-127. doi: 10.1016/S0967-070X(02)00011-2.

Boschetti, F., Gaffier, C., Moglia, M., Walke, I., \& Price, J. (2017). Citizens' perception of the resilience of Australian cities. Sustainability Science, 12(3), 345-364. doi: 10.1007/s11625-017-0429-1.

Brazilian Public Security Forum - FBSP. (2018). Public Safe is the solution - 2018. São Paulo: FBSP. Retrieved on March 8, 2020, from forumseguranca.org.br/

Carr, K., \& Spring, G. (1993). Public Transport Safety: A Community Right and a communal Responsibility. Crime Prevention Studies, 147-155.

Carvalho, I. S. de, \& Risso, M. Í. (2018). Segurança Pública para virar o Jogo. Rio de Janeiro: Zahar.

Castro, D., Sousa, B. de, Souza, C., Ii, P., Santos, S., Ii, R., \& Rita, A. (2017). Violência em transporte público: uma abordagem baseada em análise espacial. Rev Saude Publica, 51, 1-10. doi: 10.11606/S1518-8787.2017051007085

Confederação Nacional da Indústria - CNI. (2018). Retratos da Sociedade Brasileira. Confederação Nacional da Indústria, $7(41), 1-14$.

Cosenza, C., Sandres, G., Junior, P. S., \& Siggete, E. (2016). CRFM: An application of the fuzzy logic in APELL programme. International Journal of Safety and Security Engineering, 6(1), 63-72. doi:10.2495/SAFE-V6-N1-63-72.

Cury, M. V. Q. (2007). Método para avaliar a percepção do usuário sobre a qualidade de ST sobre trilhos. Transportes, 15(1), 7-15.

de Souza, E. R., \& de Lima, M. L. C. (2006). Panorama da violência urbana no Brasil e suas capitais. Ciência de saúde coletiva, 11(supl), 1211-1222.

Faizi, S., Rashid, T., Sałabun, W., Zafar, S., Wątróbski, J. (2018). Decision Making with Uncertainty Using Hesitant Fuzzy Sets. International Journal of Fuzzy Systems, 20, 93-103.

Fajnzylber, P., \& Araujo Jr, A. de. (2001). Violência e criminalidade [Violence and criminality]. Minas Gerais: CEDEPLAR. Retrieved on March 8, 2020, from https://econpapers.repec.org/RePEc:cdp:texdis:td167

Folke, C. (2006). Resilience: The emergence of a perspective for social-ecological systems analyses. Global Environmental Change, 16(3), 253-267. doi: 10.1016/j.gloenvcha.2006.04.002.

Gaitanidou, E., Tsami, M., \& Bekiaris, E. (2017). A review of resilience management application tools in the transport sector. Transportation Research Procedia, 24, 235-240. doi: 10.1016/j.trpro.2017.05.113.

Hernández, D. (2012). Activos y estructuras de oportunidades de movilidad. Una propuesta analítica para el estudio de la accesibilidad por transporte público, el bienestar y la equidad. EURE, 38(115), 117-135.

Kim, H., \& Song, Y. (2018). An integrated measure of accessibility and reliability of mass transit systems. Transportation, 45(4), 1075-1100. doi: 10.1007/s11116-018-9866-7.

Kooi, B. (2015). Security Concerns at Hot-Spot Bus Stop Locations. Journal of Applied Security Research, 10(3), $277-307$. 
doi:10.1080/19361610.2015.1038762.

Kruger, T., \& Landman, K. (2007). Crime and Public transport: designing a safer journey. In Annals of the XXVI Annual Southern African Transport. South Africa: SATC.

Langridge, R., Christian-Smith, J., \& Lohse, K. A. (2006). Access and resilience: Analyzing the construction of social resilience to the threat of water scarcity. Ecology and Society, 11(2). doi: 10.5751/ES-01825-110218.

Marchese, D., Reynolds, E., Bates, M. E., Morgan, H., Clark, S. S., \& Linkov, I. (2018). Resilience and sustainability: similarities and differences in environmental management applications. Science of the Total Environment, 613-614, 1275-1283. doi: 10.1016/j.scitotenv.2017.09.086.

Moore, S. (2011). Understanding and managing anti-social behaviour on public transport through value change: The considerate travel campaign. Transport Policy, 18(1), 53-59. doi: 10.1016/j.tranpol.2010.05.008.

Moreira, R. do C., \& Fochezatto, A. (2017). Análise espacial da criminalidade no estado da Bahia. Rde - Revista de Desenvolvimento Econômico, 1(39), 52-80.

Newton, A. D. (2004). Crime on Public Transport: 'Static' and 'Non-Static' (Moving) Crime Events. Western Criminology, $5(3), 25-42$.

Newton, A. (2014). Crime on Public Transport. In G. Bruinsma, \& D. Weisburd (eds.), Encyclopedia of Criminology and Criminal Justice (pp. 709-720). New York, NY: Springer New York.

Proper, J. W., \& Pienaar, W. J. (2011). Resilience as an imperative in public transport organisations. Corporate Ownership and Control, 8(4 D), 373-388. doi: 10.22495/cocv8i4c3art6.

Reggiani, A., Nijkamp, P., \& Lanzi, D. (2015). Transport resilience and vulnerability: The role of connectivity. Transportation Research Part A: Policy and Practice, 81, 4-15. doi: 10.1016/j.tra.2014.12.012.

Rolim, M. (2007). Caminhos para a inovação em segurança pública no Brasil. Revista Brasileira de Segurança Pública, 1(1), $32-47$.

Santos, T. F., Silva, M. A. V., Fernandes, V. A., \& Mardsen, G. (2020). Resilience and Vulnerability of Public Transportation Fare System: the case of the city of Rio de Janeiro, Brazil. Sustainability, 12, 1-22. doi: https://doi.org/10.3390/su12020647

Sałabun, W., Palczewski, K., Wątróbski, J. (2019). Multicriteria Approach to Sustainable Transport Evaluation under Incomplete Knowledge: Electric Bikes Case Study. Sustainability, 11, 1-19, doi: https://doi.org/10.3390/su11123314.

Sałabun, W. (2014). Reduction in the Number of Comparisons Required to Create Matrix of Expert Judgment in the Comet Method. Manag. Prod. Eng. Rev., 5, 62-69.

Spaans, M., \& Waterhout, B. (2017). Building up resilience in cities worldwide - Rotterdam as participant in the 100 Resilient Cities Programme. Cities, 61, 109-116. doi: 10.1016/j.cities.2016.05.011.

Vinodh, S., \& Devadasan, S. R. (2011). Twenty criteria based agility assessment using fuzzy logic approach. Int. J. Adv. Manuf. Technol., 54, 1219-1231.

Wang, C.-H., Chen, N., \& Chan, S.-L. (2017). A gravity model integrating high-speed rail and seismic-hazard mitigation through land-use planning: Application to California development. Habitat International, 62, 51-61. doi: 10.1016/j.habitatint.2017.02.009.

Xu, H., \& Xue, B. (2017). Key indicators for the resilience of complex urban public spaces. Journal of Building Engineering, 12, 306-313. doi: 10.1016/j.jobe.2017.06.018.

Yager, R. R. (2000). Simultaneous solution of fuzzy models: An application to economic equilibrium analysis. Fuzzy Sets and Systems, 115, 339-349. doi: 10.1016/S0165-0114(98)00117-1.

\section{Editor: Fábio Duarte}

Received: Jun. 20, 2020

Approved: Nov. 10, 2020 